Primeira submissão em 03/04/03 Ultima submissão em 31/07/03 Aceito para publicação em 02/09/03 Publicado em 20/06/04

\title{
Multivariate allometry and myocardium abnormalities during experimental systemic nitric oxide blockage
}

\author{
Alometria multivariada e anormalidades do miocárdio durante bloqueio sistêmico da síntese de óxido nítrico
}

Ricardo Xavier-Vidal113,4; Santiago Segundo Ramirez Carvajal2, 4; Sônia Baptista da Cunha²; Kalil Madi11,3

\section{key words abstract}

Hypertension

Myocyte

Morphometry

Multivariate analysis

Multivariate allometry

NO

Using allometry to evaluate numerical data from normal and experimental hypertensive rats' myocardium, thirteen normotensive Wistar male young rats were examined. Hearts were processed using histological routine methods. For myocardial quantification we utilized an M-42 Test-System. Fifteen fields were randomly considered. Parameters utilized: volumetric density $(\mathrm{Vv} \%)$; volume $\left(\mathrm{V} \mu \mathrm{m}^{3}\right)$ and cardiac weight. The $\chi^{2}$ proposed by Anderson and the F proposed by Jolicoeur were utilized to test the isometric hypothesis in multivariate allometry. Results in the first analysis show eigenvalues at first principal component with proportions of $70.11 \%$. Results concerning coefficients show $V$ nuclei with a coefficient greater than the isometric point. In the second analysis, eigenvalues of first principal component show a proportion of $75.68 \%$, using three variables. Results of the second analysis show Vv matrix with a coefficient greater than the isometric point. In the third analysis, eigenvalues of first principal component show a proportion of $70.18 \%$, using three variables. Results of the third analysis show $\vee$ nuclei with a coefficient greater than the isometric point. This suggests that the nuclei of the myocytes have the major variance between the variables utilized. Using $\chi^{2}$ and $\mathrm{F}$ tests we rejected isometric hypothesis. Then we can clearly identify the growth center advocated by Huxley as the myocyte nuclei. In conclusion, the data show that under this experimental hypertension, myocytes undergo intense nuclear changes probably involving great metabolic activities. In other words, these data also suggested that, to researchers interested in L-Name models on the $21^{\text {st }}$ day of submission, it is important to emphasize cardiomyocyte nuclei and occurrences linked to them.

resumo

Utilizamos alometria para avaliar dados numéricos experimentais oriundos do miocárdio de ratos machos jovens normais e induzidos à hipertensão. Os corações foram processados com uso de métodos histológicos de rotina. Para as quantificações miocárdicas, utilizamos um Sistema-Teste M-42. Quinze campos microscópicos aleatórios foram considerados. Os parâmetros utilizados foram: densidade volumétrica (Vv \%); volume $\left(V \mu m^{3}\right)$ e peso cardíaco. $O$ teste do $\chi^{2}$ proposto por Anderson e o teste F proposto por Jolicoeur foram utilizados de forma a testar a hipótese isométrica na alometria multivariada. Os resultados na primeira análise demonstraram os autovalores do primeiro componente principal com proporções de $70,11 \%$. Os resultados relativos aos coeficientes mostraram o V nuclear com coeficiente maior que o ponto isométrico. Na segunda análise, os resultados mostraram os autovalores do primeiro componente principal com proporções de $75,68 \%$, usando três variáveis. Os resultados relativos aos coeficientes mostraram o $\mathrm{Vv}$ da matriz com coeficiente maior que o ponto isométrico. Na terceira análise, foram mostrados os autovalores do primeiro componente principal com proporções de $70,18 \%$, usando três variáveis. Os resultados relativos aos coeficientes mostraram o V nuclear com coeficiente maior que o ponto isométrico. Isso sugere que os núcleos dos miócitos possuem a maior variância entre as três variáveis avaliadas. Usando os testes $\chi^{2}$ e F rejeitamos a hipótese isométrica. Assim, nós pudemos claramente identificar, no presente trabalho, o volume dos núcleos dos miócitos como o centro de crescimento defendido por Huxley. Concluindo, nossos dados mostram que, nessa hipertensão experimental, os miócitos apresentam intensas alterações nucleares, provavelmente envolvendo grandes atividades metabólicas. Em outras palavras, nossos dados sugerem que, para os pesquisadores interessados no modelo L-Name aos 21 dias de submissão, é importante enfatizar os núcleos dos cardiomiócitos e os eventos a eles relacionados.

\section{unitermos}

Hipertensão

Miócito

Morfometria

Análise multivariada

Alometria multivariada

ON

L-Name

1. Post-Graduate Program on Morphologic Sciences (PCM), Universidade Federal do Rio de Janeiro (UFRI).

2. Department of Statistics of Instituto de Matemática, Centro de Ciências Matemáticas e da Natureza (CCMN), UFR).

3. Hospital Universitário Clementino Fraga Filho (HUCFF), UFR).

4. Department of Science and Technology, Associação Xavier-Vidal para Direitos Humanos, Ciência, Tecnologia e Desenvolvimento (AXV).

This work is part of the PhD thesis of the main author (PCM-ICB-UFRI), which received honor mention in the XXIII Brazilian Congress of Pathology - 2000. 


\section{Introduction}

Nitric oxide (NO) is an endothelium vasorelaxing factor. Its experimental deficit produces morbid changes in animals and its deficit has been suggested to be involved in human diseases ${ }^{(4,6,14,22,23,27,28,30,36-38)}$. The concept of allometry was introduced in modern biology by Huxley at the beginning of this century ${ }^{(15,16)}$. The aim of allometry is to study the relationship between size and shape of organs and organisms ${ }^{(24)}$. The statistic multivariate methods based on the normal distribution are extensively developed and can be used in a rather organized and systematic way ${ }^{(1)}$. Multivariate allometry is based on coefficients of the first principal component. In multivariate allometry, an isometric value is interposed between the coefficients of the first principal component to evaluate the degree of growth of the first combination ${ }^{(18,33)}$. Specific growth rates are proportional to coefficients in the first principal component at covariance matrix of logarithms. It is also to be noted that the growth center advocated by Huxley ${ }^{(16)}$ corresponds to a variable showing the highest coefficient at first eigenvector, then growth gradient can be easily identified considering the magnitude of coefficients ${ }^{(32)}$. First principal component can thus be interpreted as a growth vector viewed from multivariate allometry ${ }^{(3,32) .}$

The aim of this work is to evaluate principal component analysis and multivariate allometry data from normal and experimental hypertensive animals submitted to L-Name model on day 21 in order to identify the main tissue changes.

\section{Material and method}

\section{Sample and tissue treatment}

Thirteen normotensive Wistar male young rats belonging to several breeds were used with initial weight ranging from 250 to 386 grams. Seven rats were submitted during 21 days to L-Name (Hydrochloride of $\mathrm{N}^{\omega}$-nitro-L-arginine methyl ester, Sigma Chemical, St. Louis) concentration $=75 \mathrm{mg} / 100 \mathrm{ml}^{(28,36,37)}$. Six rats were used as a control group. Arterial pressure was obtained by means of a pletismography ${ }^{(8,28,40)}$. On day 21 of the experiment an autopsy was performed, the hearts were weighted, fixed by Bouin fixative (48 hours), processed using routine methods, and stained using Masson's trichrome. Fifteen random fields were considered in each left myocardium using disector method. We utilized an M-42 Test-System coupled to an ocular lens (10x) and an immersion objective lens (100x). The counting was performed considering the points and number of structures included in a Test-System considering forbidden line ${ }^{(10-13,31)}$. The following parameters were considered:

A) Vv\%: volume density ${ }^{(7,35)}$

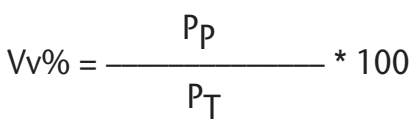

Where: $\mathrm{P}_{\mathrm{P}}=$ points counting; $\mathrm{P}_{\mathrm{T}}=$ total points of the testsystem (42 points).

B) Nv $\left(1 / \mathrm{mm}^{3}\right)$ : disector's numerical density $(10,11,13,31)$

$\mathrm{Nv}=\frac{\Sigma \mathrm{Q}-}{\Sigma \mathrm{V}(\text { dis })}$

$V_{(\text {dis })}=\mathrm{t} \times \mathrm{A}_{\mathrm{T}}$

Where: $V_{(\text {dis })}=$ volume of the disector; $t=$ thickness of microtomy; $A_{T}=$ area of the test system; $\Sigma Q^{-}=$sum of the structure counting in one face of the section; $\Sigma \mathrm{V}_{\text {(dis) }}$ = sum of volume of the disector.

C) $\mathrm{Vp}(\mu \mathrm{m} 3)$ : ponderal volume ${ }^{(7)}$

$\mathrm{Vp}=\mathrm{Vv} / \mathrm{Nv}$

\section{Principal component analysis and multivariate allometry}

Principal components are a linear combination of random or statistical variables which have special properties in terms of variances and the first principal component is a normalized linear combination with maximum variance ${ }^{(2)}$. The principal components were obtained from eigenvalues of a covariances matrix. Each eigenvalue determines a correspondent eigenvector. The first principal component corresponds to the greatest eigenvalue and explained greatest part of the total variation. Frequently only two or three principal components are involved in a great proportion of variance that makes the others negligible. Good results are obtained when the original variables possess a great degree of correlation (Pearson and/or Pearlman correlations may be used), and, if this is the case, several variables may be fully represented by two or three principal components ${ }^{(2,20,21)}$. In multivariate allometry, we interposed an isometric value between coefficients of the first principal component to evaluate the degree of growth at first combination ${ }^{(2,20,21)}$. Isometry is considered to be performed as $1 / \sqrt{ } p$, where $p$ is the number of variables ${ }^{(33)}$. The $1 / \sqrt{ } p$ value is justified because coefficients of the first 
principal component have the sum of its square equal to 1 . In the isometric hypothesis all the coefficients are equal and the square of each one is $1 / p$. Then in the isometric hypothesis, the value of each coefficient is $1 / \mathrm{Jp}$.

To check isometry hypothesis of the growth vector we utilized the two following tests:

\section{Anderson's formula ${ }^{(3, \text { appendix } B) \text { : }}$}

$\chi^{2}=\mathrm{n}\left(\mathrm{d}_{1} * \gamma^{\prime}, \mathrm{S}^{-1} * \gamma_{1}+\left(1 / \mathrm{d}_{1}\right) * \gamma^{\prime}, \mathrm{S} \gamma_{1}-2\right)$

Where: $\mathrm{n}=$ sample number; $\mathrm{d}_{1}=$ the greatest eigenvalues; $\gamma_{1}=$ coefficient vectors of the principal component; $\gamma_{1}^{\prime}=$ transpose vector of $\gamma_{1} ; S=$ matrix (of $p$ order) of sample variance and covariance, or then, correlation matrix if they are utilized instead of variance and covariance matrix; $\mathrm{S}^{-1}=$ inverse matrix of $S$. In our case, $S$ is the covariance matrix of logarithms for observed values.

The $\chi^{2}$ statistics above described has an asymptotic distribution as chi-square test with $p-1$ degrees of freedom, where $\gamma_{1}^{\prime}=\gamma_{1.0}^{\prime}=(1 / \sqrt{ } p, 1 / \sqrt{ } p, \ldots, 1 / \sqrt{ } p)$. Concerning a given $\alpha$ level of significance we obtain the value $\chi_{p-1}^{2}(\alpha)$ in the chi-square table. If the obtained value is lesser than the value calculated in the above described formula $\left(\chi^{2}\right)$ we reject the isometry hypothesis ${ }^{(3)}$.

\section{Jolicoeur's formula ${ }^{(17)}$ :}

This test, that can be used for any principal component, follows the Snedecor's F distribution on $p-1$ and N-p degrees of freedom. It can be written as:

$\mathrm{F}=(n-p)\left(\underline{\gamma}_{i} S \underline{\gamma}_{i}^{\prime} \underline{\gamma}^{S} \underline{\gamma}^{-1} \underline{\gamma}_{i}^{\prime}-1\right) /(p-1)$

Where $\gamma_{i}$ is the vector of coefficients in the first principal component, $n$ is the sample size, $p$ is the number of variables and $S$ is a sample covariance matrix. In our case, vector $\underline{\gamma}_{i}$ is an isometric vector:

$(1 / \sqrt{\mathrm{p}}, 1 / \sqrt{\mathrm{p}}, \ldots, 1 / \sqrt{\mathrm{p}})$

and $\mathrm{S}$ is the variance-covariance matrix of logarithms for observed values.

In this work for principal component analysis with $\log _{e}$ transformation of variables SAS software version 6.04 was utilized.

\section{Results}

Our results demonstrated wide abnormalities in arterial myocardial vessels of rats submitted to L-Name. Both in

left and right myocardium out at infarct areas of animals submitted we found proliferation of both arterial muscle cells and cells in the intimal layer. We also found thickening of the arterial wall with regenerative fibrotic process, intramural fibrosis and degenerative processes with vascular lumen obliteration.

Concerning multivariate analysis, three analysis of data were performed. In the first analysis we considered four variables: volume of the nuclei, cardiac weight, volume density of the matrix and volume of myocyte. In this analysis, eigenvalues of first, second, third and forth principal components of correlation matrix were equal to $0.2865,0.1087,0.0090$ and 0.0043 , with proportions of $70.11 \%, 26.6 \%, 2.23 \%$ and $1.06 \%$, respectively. Then, first principal component accounts for $70.11 \%$ of the total variance using four variables. Using first principal component (Prin1), results concerning coefficients of the principal component for multivariate allometrical appreciation are shown in Table 1. For the first analysis the isometric point was calculated as $0.5(1 / \sqrt{ } p$, where the number of variables $p$ is equal to 4 ; then, $1 / \sqrt{ } 4=0.5$ ). Results concerning coefficients show volume of the nuclei with coefficients greater than the isometric point, and cardiac weight, $\mathrm{V} v$ of matrix and volume of myocyte with coefficients inferior to the isometric point (Table 1).

In the second analysis, despite the volume of the nuclei, the set of variables was the same as that of the first analysis. In this case, eigenvalues of first, second and third principal components of correlation matrix were equal to $0.109,0.027$ and 0.0081 , with proportions of $75.68 \%$, $18.14 \%$ and $5.59 \%$, respectively. Then, the first principal component accounts for $75.68 \%$ of total variance using

Eigenvector coefficients of first principal component (coefficients Table 1 of Prin1) in the first analysis

\begin{tabular}{|c|c|c|}
\hline 1 & V nuclei & 0.93713 \\
\hline Isometry & & 0.5 \\
\hline 2 & CW & 0.26791 \\
\hline 3 & Vv matrix & 0.19284 \\
\hline 4 & V myocyte & 0.11326 \\
\hline \multicolumn{3}{|c|}{$\begin{array}{l}V \text { nuclei = volume of the nuclei; } C W=\text { cardiac weight; } V v \text { matrix = volume density } \\
\text { of the matrix; } V \text { myocyte = volume of myocyte. Isometric point (Isometry): } 1 / J_{p} \text {, } \\
\text { where the number of variables } p \text { is equal to } 4 \text {, then } 1 / \sqrt{ } 4=0.5 \text {. Results concerning } \\
\text { coefficients show volume of the nuclei with coefficients greater than the isometric } \\
\text { point, and cardiac weight, } V v \text { of matrix and volume of myocyte with coefficients } \\
\text { inferior to the isometric point. In this case the growth center advocated by Huxley is } \\
\text { clear and in the first analysis ( } V \text { nuclei; CW; Vv matrix; } V \text { myocyte) the growth center } \\
\text { is the volume of nuclei. }\end{array}$} \\
\hline
\end{tabular}


Eigenvector coefficients of first principal component (coefficients

Table 2 of Prin1) in the second analysis

\begin{tabular}{lcc}
\hline 1 & Vv matrix & 0.98682 \\
Isometry & & 0.577 \\
2 & $\mathrm{CW}$ & 0.15985 \\
3 & V myocyte & 0.02507 \\
\hline
\end{tabular}

$V_{v}$ matrix = volume density of the matrix; $C W=$ cardiac weight; $V$ myocyte $=$ volume of myocyte. Isometric point (Isometry): $1 / \mathrm{Np}$, where the number of variables $p$ is equal to 3 , then $1 / \sqrt{ } 3=0.57735$. Results in the second analysis concerning coefficients at first principal component show $V_{v}$ of matrix with coefficient greater than the isometric point, and cardiac weight and volume of myocyte with coefficients inferior to the isometric point. Note that in this case the nuclei were not considered. In this case the growth center advocated by Huxley is clear and in the second analysis (Vv matrix; CW; V myocyte) the growth center is Vv matrix.

three variables. Using the first principal component (Prin1), results are shown in Table 2 . For the second analysis the isometric point was calculated as $0.57735(1 / \mathrm{V} p$, where the number of variables $p$ is equal to 3 ; then, $1 / \sqrt{ } 3=0.57735$ ). Results in the second analysis concerning coefficients at first principal component show $\mathrm{V} v$ of matrix with coefficient greater than the isometric point, and cardiac weight and volume of myocyte with coefficients inferior to the isometric point (Table 2). Note that in this case the nuclei were not considered.

In the third analysis we included the volume of the nuclei but cardiac weight was pushed out. In this case, the eigenvalues of first, second and third principal components of correlation matrix were equal to $0.2666,0.1087$ and 0.0046 , with proportions of $70.18 \%, 28.61 \%$ and $1.22 \%$, respectively. Then, the first principal component accounts for $70.18 \%$ of total variance using three variables. Using the first principal component (Prin1), results are shown in Table 3. For the third analysis the isometric point was calculated as $0.57735(1 / \sqrt{ } p$, where the number of variables $p$ is equal to 3 ; then, $1 / \sqrt{3}=0.57735)$. Results in the second analysis concerning coefficients for the first principal component show volume of nuclei with coefficient greater than the isometric point, and $\mathrm{V} v$ matrix and $\mathrm{V}$ myocyte had coefficients inferior to the isometric point (Table 3).

Checking isometric hypothesis of growth vector, utilizing the chi-square test, $\chi^{2\left(3 \text {, appendix }{ }^{B)}\right.}$; and F-test ${ }^{(17)}$, the results show that in all analyses it was rejected because the $p$ value, in all three cases, was inferior to 0.05 (Tables 4 and 5). Then, it means that the variables studied in each analysis do not tend to isometry. In this case the growth center advocated by Huxley is clear and in the first analysis
( $V$ nuclei; CW; Vv matrix; V myocyte) the growth center is the volume of nuclei. In the second analysis ( $V v$ matrix; $C W ; V$ myocyte) the growth center is $V v$ matrix and in the third analysis ( $V$ nuclei; $V v$ matrix; $V$ myocyte) the growth center is also volume of nuclei.

Eigenvector coefficients of first principal component (coefficients Table 3 of Prin1) in the third analysis

\begin{tabular}{lcc}
\hline 1 & V nuclei & 0.97309 \\
Isometry & & 0.577 \\
2 & Vv matrix & 0.19739 \\
3 & V myocyte & 0.11889 \\
\hline
\end{tabular}

$V$ nuclei = volume of the nuclei; $V_{v}$ matrix = volume density of the matrix; $V$ myocyte $=$ volume of myocyte. Isometric point (Isometry): $1 / \mathrm{N} p$, where the number of variables $p$ is equal to 3 , then $1 / \sqrt{ } 3=0.57735$. Results in the third analysis concerning coefficients for first principal component show volume of the nuclei with coefficient greater than the isometric point, and $V v$ matrix and $V$ myocyte had coefficients inferior to the isometric point. In this case the growth center advocated by Huxley is clear and in the third analysis (V nuclei; Vv matrix; V myocyte) the growth center is also volume of nuclei.

Results of chi-square test $\left(\chi^{2}\right)$ in the isometric hypothesis for growth

Table 4 vector (Anderson's test) ${ }^{(3)}$

\begin{tabular}{lcc} 
& $\chi^{2}$ & $p$ values \\
$1^{\text {st }}$ analysis & 214.416 & 0 \\
$2^{\text {nd }}$ analysis & 36.821 & 0.00000005 \\
$3^{\text {rd }}$ analysis & 181.613 & 0 \\
\hline
\end{tabular}

$p$ value $<0.05$ leads to reject the isometric hypothesis. Checking the isometric hypothesis of growth vector, utilizing the chi-square test, $\chi^{2}$, the results show that in all analyses it was rejected because the $p$ value in all three cases was inferior to 0.05 . Then, it means that the variables studied in each analysis do not tend to isometry. In this case the growth center advocated by Huxley is clear.

Results of $F$ test of the isometry hypothesis for growth vector Table 5 (Jolicoeur's test) ${ }^{(17)}$

\begin{tabular}{ccc}
\hline & F & $p$ values \\
\hline $1^{\text {st }}$ analysis & 29.512 & 0.000112 \\
$2^{\text {nd }}$ analysis & 7.005 & 0.012532 \\
$3^{\text {rd }}$ analysis & 42.361 & 0.000026 \\
\hline
\end{tabular}

$p$ value $<0.05$ leads to reject the isometric hypothesis. Checking isometric hypothesis of growth vector, utilizing the F test, the results show that in all analyses it was rejected because the $p$ value in all three cases was inferior to 0.05 . Then, it means that the variables studied in each analysis do not tend to isometry. In this case the growth center advocated by Huxley is clear. 


\section{Discussion}

Statistical multivariate analysis, including multivariate allometry, has been widely defined and discussed. These methods have also wide application, for instance, to evaluate variations concerning growth of biological populations, organisms or organs and also organic structures both concerning normal or abnormal development $\left.{ }^{(1-3,5,9,}, 15-17,21,24-26,29,32-34,39\right)$.

Multivariate allometry evaluates the eigenvectors of the first principal component. In summary, principal component analysis just involves finding eigenvalues of covariance matrix sample. The eigenvalue indicates a value of variance that contributes to its total. For example, if the total variance is five and an eigenvalue found is 3.616 , the contribution of this component for the total variance is $72.3 \%$. In this case, this component is the first principal component ${ }^{(21)}$. In multivariate allometry, we interpose an isometric value between the eigenvector coefficients of first principal component to evaluate the degree of growth in the first combination ${ }^{(18,33)}$. Jolicoeur ${ }^{(18)}$ defined isometry as equality for all components in eigenvector corresponding to the largest eigenvalue. Mosimann defines isometry as an independence between a shape vector and a given size of variable. Mosimann's results help us to avoid some of the difficulties associated with Jolicoeur's definition of isometry when there is not even a straight line relationship between logarithms. From the theoretical viewpoint Mosimann shows different standard size of variables as to be appropriate for isometry in each case. Mosimann generalizes this idea to $p$ dimensions and defines shape vectors and size variables associated with a set of $p$ distances between specified points ${ }^{(25,26,29)}$. Anderson proposed a criterion ${ }^{(3)}$ for testing isometry. Nevertheless, Anderson's criterion ${ }^{(3)}$ is an asymptotic one, then it is not the ideal for small samples. The small-sample procedure was proposed by Jolicoeur( ${ }^{(17)}$, using the $F$ distribution instead of $\chi^{2}$. It should be noted that unlike Anderson's criterion, Jolicoeur's procedure does not associate the hypothetical vector with any particular characteristic root of the sample covariance matrix $S$.

In our study, results concerning mathematics in the first analysis showed the eigenvalues of first principal component of covariance matrix with a proportion of $70.11 \%$ (four variables) and the isometric point was 0.5 . Results concerning coefficients show $V$ nuclei with coefficients greater than the isometric point (positive allometry). In the second analysis (without $V$ nuclei) the eigenvalues of first principal component of covariance matrix showed a proportion of $75.68 \%$ (three variables) and the isometric point was 0.57735 . Results of the second analysis show Vv matrix with coefficient greater than the isometric point (positive allometry). In the third analysis the eigenvalues of first principal component of covariance matrix showed a proportion of $70.18 \%$ (three variables) and the isometric point was 0.57735 . Results of the third analysis show again the $\mathrm{V}$ nuclei with coefficient greater than the isometric point (positive allometry). Our results suggest that volume of myocyte nuclei has the major variance between variables utilized. Testing isometry $(3,17)$, we rejected the isometric hypothesis. In this case the terms positive and negative allometry are correct. Rejecting the isometric hypothesis we can clearly identify the growth center advocated by Huxley ${ }^{(16)}$, as volume of myocyte nuclei. Increasing volume of cardiomyocyte and cardiomyocyte nuclei during morbid cardiac hypertrophy were identified several years ago ${ }^{(19)}$. In this work, we performed a quantitative study concerning morbid hypertrophy cardiac process occurring in rats submitted to nitric oxide blockage during 21 days. A general myocardial qualitative study on day 21 was previously performed by our laboratory ${ }^{(36,37)}$. Our anatomopathologic results in the present work showed vascular abnormalities and fibrotic areas in the myocardium of submitted rats. In both left and right myocardium - out of the infarct areas - we have found proliferation of arterial muscle cells and cells in the intimal layer. We also identified thickening of the arterial wall with regenerative fibrotic process. Our present results are also similar to those that showed abnormalities and lesions that occurred at least in some cases of hypertension, cardiomyopaties and arteriosclerosis in mankind.

\section{Acknowledgments}

The main author thanks the unique and eternal God and His Son Jesus Christ. The main author had a PhD fellowship from Capes, Brasilia/Brazil. This article was supported by Capes, CNPq, CIC-HUCFF/UFRJ and AXV. The main author thanks the families Xavier and Vidal, especially José Vandir Jorge Vidal (in memoriam) and Marina Xavier Vidal. The main author also thanks the first Baptist Church of Niterói (RJ) because their spiritual support.

\section{References}

I.ANDERSON,T.W.An Introduction to Multivariate Statistical Analysis. New York: John Wiley \& Sons, 1958.
2.ANDERSON,T.W.An Introduction to Multivariate Statistical Analysis. New York: John Wiley \& Sons, 1984. 
3. ANDERSON, T. W. Asymptotic theory for principal component analysis. Annals of Mathematical Statistics, v. 34, p. 122-48, 1963.

4. BABAL, P. et al. Chronic inhibition of $\mathrm{NO}$ synthesis produces myocardial fibrosis and arterial media hyperplasia. Histol Histopathol, v. I 2, n. 3, p. 623-9, 1997.

5. BROOKSTEIN, F. L. Size and shape spaces for landmark data two dimensions. Statistical Sciences, v. I, n. 2, p. I81-242, 1986.

6. CAREY, R. M. et al. Nitric oxide: a physiological mediator of the type 2 (AT2) angiotensin receptor. Acta Physiol Scand, V. 168, p. 65-7I, 2000.

7. CRUZ-ORIVE, L. M.;WEIBEL, E. R. Recent stereological methods for cell biology: a brief survey. Am J Physiol, v. 258, LI48LI56, 1990.

8. FISCHER, M. et al. Effects of combined renovascular hypertension and diabetes mellitus on myocardial cells, non-vascular interstitium and capillaries: a stereological study on rat hearts. Virchows Arch A, v. 420, p. 499-506, 1992.

9. GRIFFITHS, D;:SANDLAND, R. Fitting generalized allometric models to multivariate growth data. Biometrics, v. 40, p. 139-50, 1984.

10. GUNDERSEN, H. J. G. et al. Some new, simple and efficient stereological methods and their use in pathological research and diagnosis. APMIS, v. 96, p. 379-94, 1988a.

I I. GUNDERSEN, H.J. G. et al.The new stereological tools: disector, fractionator, nucleator, and point sampled intercepts and their use in pathological research and diagnosis. APMIS, v. 96, p. 857-8I, 1988b.

12. GUNDERSEN, H. J. G. Notes on the estimation of numerical density of arbitrary profiles: the edge effect. J Microsc, v. I I I, p. 219-23, 1977.

13. GUNDERSEN, H. J. G. Stereology of arbitrary particles. A review of unbiased number and size estimators and the presentation of some new ones, in memory of William R. Thompson.J Microsc, v. I43, p. 3-45, 1986.

14. HAYAKAWA, H.; RAll, L. The link among nitric oxide synthase activity, endothelial function, and aortic and ventricular hypertrophy in hypertension. Hypertension, v. 29, n. 2, p. 235-4I, 1997.

15. HUXLEY, J. S. Constant differential growth ratios and their significance. Nature, v. I | 4, p. 895-6, 1924.

16. HUXLEY, J. S. Problem of relative growth. London: Methuen and Company Ltd., 1932.

17. JOLICOEUR, P. Principal components, factor analysis and multivariate allometry: a small sample direction test. Biometrics, v. 40, p. 685-90, 1984.

18. JOLICOEUR, P.The multivariate generalization of the allometry equation. Biometrics, v. 19, p. 497-9, 1963.

19. KISSANE, J. M.; ANDERSON, P. Anderson's Pathology. St. Louis: The CV Mosby Company, 1985.

20. KSHIRSAGAR, A. M. Multivariate Analysis. New York: Marcel Dekker Inc., 1972.

21. MANLY, B. F. J. Multivariate statistical methods: a primer. London: Chapman and Hall, 1986.

22. MORENO Jr, H. et al. Non-specific inhibitors of nitric oxide synthase cause myocardial necrosis in the rat. Clin Exp Pharmacol Physiol, v. 24, p. 349-52, 1997.

23. MORENO Jr, H.; NATHAN, L. P.; COSTA, S. K. P. Enalapril does not prevent the myocardial ischemia caused by the chronic inhibition of nitric oxide. Eur J Pharmacol, v. 287, p. 93-6, 1995.
24. MORRISON, D. F. Multivariate Statistical Methods. New York: McGraw-Hill Book Company, 1976.

25. MOSIMANN, J. E. Size allometry, size and shape variables with characterization of the lognormal and gamma distributions. J Am Stat Assoc, v. 65, p. 930-45, 1970.

26. MOSIMANN, J. E. Size and shape analysis of Schistosome egg-counts in Egyptian autopsy data. Biometrics, v. 34, p. 34I-56, 1978.

27.PANZA,J.A. et al. Impaired endothelium-dependent vasodilatation in patients with essential hypertension: evidence that nitric oxide abnormality is not localized to a single signal transduction pathway. Circulation, v. 91, p. 1732-8, 1995.

28. RIBEIRO, M. O. et al. Chronic inhibition of nitric oxide synthesis. A new model of arterial hypertension. Hypertension, v. 20, p. 298-303, 1992.

29. SPRENT, P. The mathematics of size and shape. Biometrics, v. 28, p. 23-37, 1972.

30. STAUSS, H. M. et al. Blood pressure control in eNOS knock-out mice: comparison with other species under $\mathrm{NO}$ blockade. Acta Physiol Scand, v. 168, p. 155-60, 2000.

3I. STERIO, D. C. The unbiased estimation of number and sizes of arbitrary particles using the disector. J Microsc, v. 134, p. 127-36, 1984.

32. TAKAl, S. A note on multivariate allometry. Acta Med Auxol, v. 8, p. 155-7, 1976.

33.TAKAI, S.;AKIOSHI,T.Association of weights of some organs during the prenatal period. Ann Hum Biol, v. 6, n. I, p. 85-7, 1979.

34. TEZUKA, F.; RYOJI, C.; TAKAHASHI, T. Morphometric and multivariate statistical detection of cancer cells in endometrial cytology. Analytic Quantitative Cytology and Histology, v. 16, n. 5, p. 332-8, 1994.

35. WEIBEL, E. R. Stereological methods. vol. I: practical methods for biological morphometry. New York: Academic Press, 1979.

36. XAVIER-VIDAL R. et al. Estudo anatomopatológico experimental em miocárdio de animais submetidos à hipertensão arterial via bloqueador da síntese do óxido nítrico. Rev Port Cardiol, v. 17, n. 2, p. 38I-9I, 1999.

37. XAVIER-VIDAL, R. Avaliação morfológica, à microscopia óptica convencional, do miocárdio ventricular de ratos Wistar submetidos ao bloqueio sistêmico da síntese do óxido nítrico. Rio de Janeiro, 2000. Thesis (PhD) - Universidade Federal do Rio de Janeiro.

38. XAVIER-VIDAL, R. Alterações morfológicas do miocárdio devidas a hipertensão arterial induzida por inibidor da síntese do óxido nítrico. Estudo experimental em ratos. Niterói, 1995. Thesis (MSc) - Universidade Federal Fluminense.

39. XAVIER-VIDAL, R. Multivariate analysis of the human heart during fetal development. Biom Res, v. 7, n. I, p. 49-55, 1996.

40. ZATZ, R. A. Low-cost tail-cuff method for estimation of mean arterial pressure in conscious rats. Lab Anim Sci, v. 42, p. |98-201, 1990.

\begin{tabular}{l|l} 
& Mailing address \\
\hline & Ricardo Xavier-Vidal \\
& Associação Xavier-Vidal para Diretos Humanos, \\
& Ciência, Tecnologia e Desenvolvimento (AXV) \\
& Alameda São Boaventura, 348 - Fonseca \\
CEP 24120-190 - Niterói-R) \\
e-mail: axv@xavier-vidal.org.br \\
Home page: http://www.xavier-vidal.org.br
\end{tabular}

